\title{
Exogenous application of plant hormones in the field alters aboveground plant-insect responses and belowground nutrient availability, but does not lead to differences in plant-soil feedbacks
}

\author{
Robin Heinen $^{1,2,3}$ (D) $\cdot$ Katja Steinauer $^{1} \cdot$ Jonathan R. De Long ${ }^{1} \cdot$ Renske Jongen $^{1} \cdot$ Arjen Biere $^{1} \cdot$ Jeffrey A. Harvey $^{1,4}$. \\ T. Martijn Bezemer ${ }^{1,2}$
}

Received: 25 September 2019 / Accepted: 17 July 2020 / Published online: 17 August 2020

(c) The Author(s) 2020

\begin{abstract}
Plant-soil feedbacks of plants that are exposed to herbivory have been shown to differ from those of plants that are not exposed to herbivores. Likely, this process is mediated by jasmonic acid (JA) and salicylic acid (SA) defense pathways, which are induced by aboveground herbivory. Furthermore, exogenous application of these phytohormones to plants alters belowground communities, but whether this changes plant-soil feedbacks in natural systems is unknown. We applied exogenous sprays of JA and SA individually and in combination to field plots in a restored grassland. Control plots were sprayed with demineralized water. After three repeated application rounds, we transplanted seedlings of the plant-soil feedback model plant Jacobaea vulgaris as phytometer plants to test the effects of potential phytohormone-mediated changes in the soil, on plant performance during the response phase. We further measured how exogenous application of phytohormones altered plant-related ecosystem characteristics (plot-level); soil chemistry, plot productivity, insect communities and predation. Biomass of the phytometer plants only co-varied with plot productivity, but was not influenced by phytohormone applications. However, we did observe compound-specific effects of SA application on insect communities, most notably on parasitoid attraction, and of JA application on soil nitrogen levels. Although we did not find effects on plant-soil feedbacks, the effects of exogenous application of phytohormones did alter other ecosystem-level processes related to soil nutrient cycling, which may lead to legacy effects in the longer term. Furthermore, exogenous application of phytohormones led to altered attraction of specific insect groups.
\end{abstract}

Keywords Herbivory $\cdot$ Salicylic acid $\cdot$ Jasmonic acid $\cdot$ Insect communities $\cdot$ Field experiment $\cdot$ Plant-soil feedback

Handling Editor: Hongbo Jiang.

Electronic supplementary material The online version of this article (https://doi.org/10.1007/s11829-020-09775-4) contains supplementary material, which is available to authorized users.

Robin Heinen

robin.heinen@tum.de

1 Department of Terrestrial Ecology, The Netherlands Institute of Ecology (NIOO-KNAW), Wageningen, The Netherlands

2 Institute of Biology, Plant Sciences \& Natural Products, Leiden University, Leiden, The Netherlands

3 Present Address: Department of Terrestrial Ecology, Technische Universität München, Wissenschaftszentrum Weihenstephan für Ernährung, Landnutzung und Umwelt, Freising, Germany

4 Department of Ecological Sciences - Animal Ecology, VU University, Amsterdam, The Netherlands

\section{Introduction}

Insect herbivores are important components of ecological processes in plant-dominated ecosystems. They comprise some of the most abundant animal species on the planet, in terms of species diversity and abundance (Price et al. 2011). Therefore, it is not surprising that virtually all plant species host a few or even many herbivorous insect species. Insect herbivores feed on plant tissues, such as roots, leaves, stems, and inflorescences. As a result, insect herbivory can affect the performance of individual plants in plant communities, and the composition of species within those communities (Wilson 1987). For instance, herbivory by insects may reduce rates of succession (Brown 1984, 1985) and plant community composition (Brown and Gange 1992; Crawley 1996; Carson and Root 2000). Some insect species even cause regional outbreaks that can wipe out or set back some 
plant species temporarily (Ludwig et al. 1978; Elkinton and Liebhold 1990). In many grassland ecosystems, the effects of insect herbivory on productivity or diversity of plant communities are limited although the impact of insects on individual plants in those communities is considerable (Hairston et al. 1960; Crawley 1989; Bagchi et al. 2014).

When insects feed on a plant, they damage plant tissues locally and release components from their saliva (Ali and Agrawal 2012) that induce the activation of defense mechanisms in the plant (Karban and Kuc 1999; Kessler and Baldwin 2002). Chewing herbivores tend to induce the production of jasmonic acid (JA), whereas phloem-feeding insects and biotrophic fungal pathogens tend to induce the production of salicylic acid (SA) (Thaler et al. 2012). The production of these phytohormones activates a systemic cascade of physiological responses in the host plant that can result in the production of secondary metabolites or the release of volatiles that attract natural enemies of the herbivores, such as predatory arthropods or parasitoids (e.g., Gols et al. 1999; Kessler and Baldwin 2001; Ozawa et al. 2004, 2008; Van Dam and Oomen 2008; Menzel et al. 2014a, b).

Plants deliver many resources to the soil by exuding organic compounds from the roots, and shedding litter into the soil (Steinauer et al. 2016; De Long et al. 2019). These plant-derived inputs influence the community of soil organisms around the roots of the plant (Philippot et al. 2013; Van der Putten et al. 2013; Pineda et al. 2017; Heinen et al. 2018a). For instance, most plants form specific mutualistic relationships with mycorrhizal fungi and interact with plant growth-promoting rhizobacteria in the soil (Gehring and Bennett 2009; Pineda et al. 2010). The soil is also home to many antagonists of plants, such as plant-parasitic nematodes, root feeding arthropods and soil pathogens (Johnson et al. 2012; Johnson and Rasmann 2015). Both JA and SA are important in mediating interactions with belowground organisms. Jasmonic acid plays a role in defense against root feeding insects, nematodes and necrotrophic pathogens (Glazebrook 2005; Thaler et al. 2012), whereas SA defends plants against biotrophic pathogens (Pieterse and Dicke 2007; Pieterse et al. 2009). Manipulation of these pathways can influence patterns of root exudation into the soil (Berendsen et al. 2012) and it has been shown that manipulation of JA and SA pathways can alter the composition of the rhizosphere community (Carvalhais et al. 2013; Lebeis et al. 2015). Plant-mediated changes in soil microbiota influence the performance of plants that grow later in the soil (plant-soil feedback, Kulmatiski et al. 2008; Van der Putten et al. 2013, 2016). Hence, manipulation of JA and SA pathways could also alter plant-soil feedbacks (conceptually represented in Fig. 1). Although foliar application of JA and SA or their chemical mimicks is commonly practiced to study plant defenses (e.g., El-Wakeil et al. 2010; Bojórquez Péreznieto et al. 2013; de Freitas et al. 2019), we are not aware studies that examine the effects of exogenous application of plant hormones on plant-mediated soil legacy effects and how they could alter plant-soil feedbacks in natural plant communities.

In three rounds, we applied exogenous sprays of solutions of SA, JA or a mixture of the two, to grassland plots that contained naturally growing plant communities. Control plots received only demineralized water. Subsequently, we recorded the effects on attraction of insects and on levels of predation on insects in the plots. Further, we assessed whether JA and SA would influence soil processes. We measured soil nutrients and organic matter, and conducted a phytometer plant assay, using Jacobaea vulgaris. This species is known to be highly sensitive to changes in soil microbial communities and plant-soil feedbacks (Wang et al. 2019; Van de Voorde et al. 2012; Kostenko et al. 2012). We hypothesized that (i) exogenous application of JA and SA individually to the plant community, through plant-mediated changes in the soil, will have a positive effect on the growth of phytometer plant $J$. vulgaris, compared to their growth in control plots that did not receive JA or SA, and that (ii) exogenous application of JA and SA together, would have additive positive effects on growth of the phytometer plant $J$. vulgaris, compared to their growth in control plots that did not receive JA or SA. Moreover, we hypothesized that (iii) application of JA and SA would suppress the attraction of chewing and phloem-feeding insects, respectively, and (iv) that application would result in attraction of natural enemies to the treated plots.

\section{Materials and methods}

\section{Experimental field}

The experiment was conducted in an experimental field based in a restoration grassland, 'De Mossel' (Ede, The Netherlands), managed by the organization Natuurmonumenten. The field was used for crop production until 1996, after which agricultural practices were ceased and the vegetation was left to develop naturally. Soils in this area are characterized as sandy loam $(94 \%$ sand, $4 \%$ silt, $2 \%$ clay, $\sim 5 \%$ organic matter, $5.2 \mathrm{pH}, 2.5 \mathrm{mg} \mathrm{kg}^{-1} \mathrm{~N}$, $4.0 \mathrm{mg} \mathrm{kg}^{-1} \mathrm{P}, 16.5 \mathrm{mg} \mathrm{kg}^{-1} \mathrm{~K}$ ) (Jeffery et al. 2017). Daily temperatures in the area average $16.7^{\circ} \mathrm{C}$ in summer and $1.7^{\circ} \mathrm{C}$ in winter. Monthly precipitation averages range from 48 to $76 \mathrm{~mm}$ (www.climate-data.org).

The experimental area was fenced in 2016, after the top layer $(\sim 5 \mathrm{~cm})$ of soil was excavated to remove existing vegetation. Then the area was left to be colonized by plants from the seedbank and the surroundings. In the following 2 years, the vegetation reached full cover and in spring 2018 at the onset of the experiment, abundant species in 
A

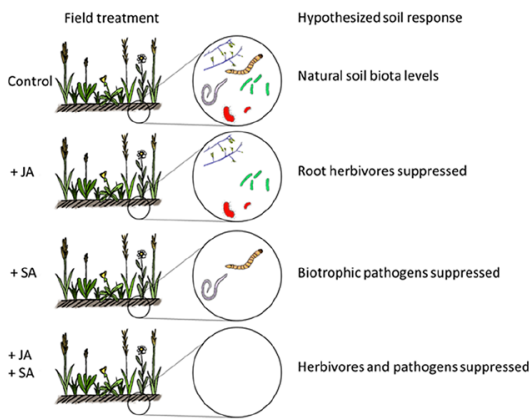

C

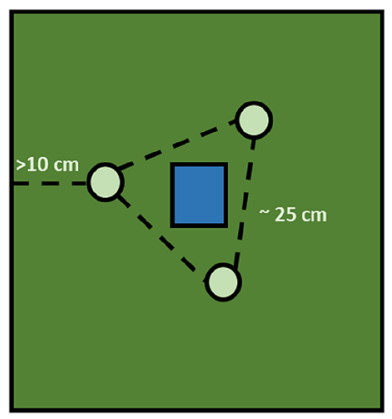

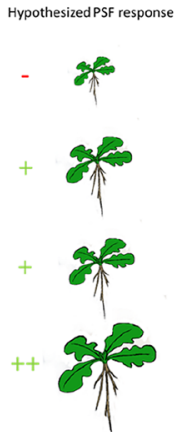

D

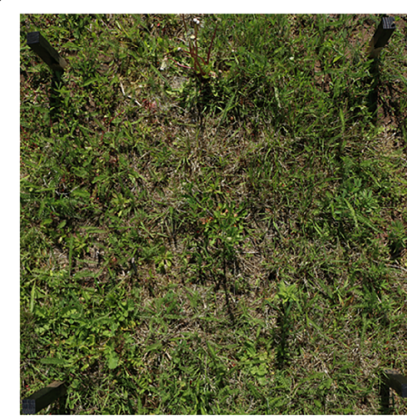

B

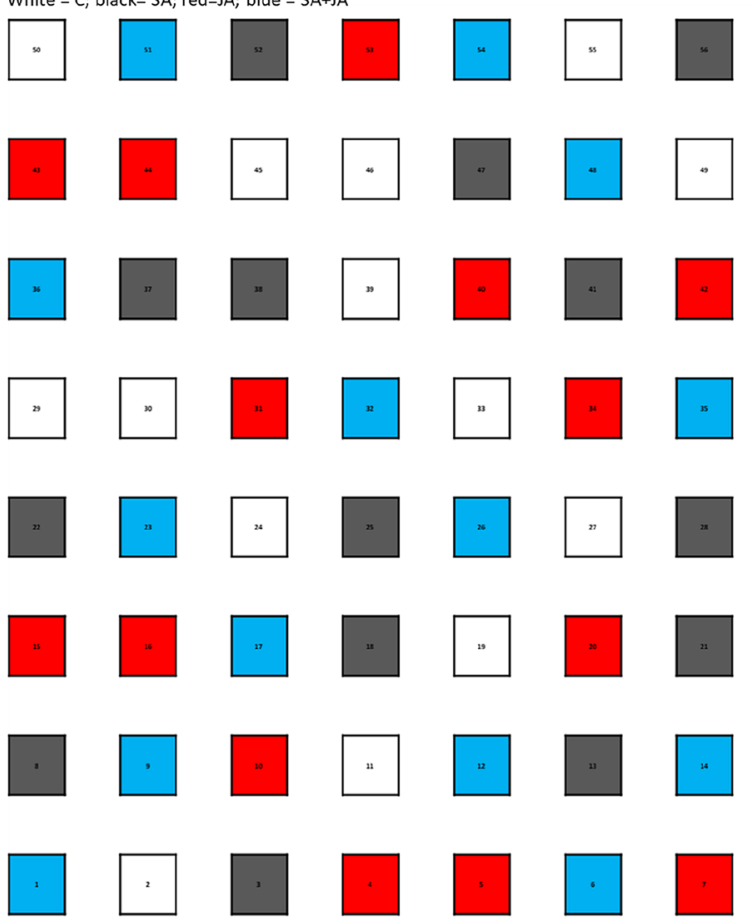

Fig. 1 a Conceptual diagram of the hypothesized effects of simulated herbivory, via exogenous application of phytohormones, on soil biota and the hypothesized plant-soil feedback responses in phytometer plants. $\mathbf{b}$ The randomized allocation of phytohormonal treatments to the selected plots. White plots indicate controls; black plots indicate salicylic acid treatment; red plots indicate jasmonic acid treatment;

the communities were the grasses Agrostis capillaris, Anthoxanthum odoratum, Aria caryophylla, Holcus lanatus, the forbs Achillea millefolium, Hypericum perforatum, Jacobaea vulgaris and the legumes Lotus corniculatus and Trifolium repens.

\section{Experimental design}

In the experimental area 56 experimental plots were laid out of $60 \times 60 \mathrm{~cm}$ each with eight rows of seven plots and $60 \mathrm{~cm}$ paths between plots, which ensured that the plots were not directly adjacent and soils of individual plots would be less likely to affect each other. Paths in between the plots were not mowed throughout the experiment. The reasons for this are as follows. First, we wanted to avoid mechanical induction of phytohormonal pathways via mowing that might influence the soils in the paths bordering the plots. Second, the natural vegetation on the paths acted as a natural 'barrier' between plots, ensuring that the plots were only different from surrounding vegetation in terms of phytohormonal treatment. Lastly, because the plots were separated only by $60 \mathrm{~cm}$ paths, and many flying insects are good dispersers, this leads to the risk that blue plots indicate combined jasmonic and salicylic acid treatments. c Conceptual overview of a typical plot, where phytometer plants (light circles) were planted equidistant in a triangle shape minimum $10 \mathrm{~cm}$ distance from the plot border and blue sticky trap (square) were placed in the plot middle. d A typical experimental plot, covered by vegetation at the onset of the experiment in May 2018

the aboveground insect collection in the different plots is not fully independent. The barrier posed by the unmown natural vegetation in the plots prevented that insects would directly disperse into adjacent plots, hence limiting the effects of non-independence.

The plots were then randomly assigned to one of four treatments, ( $n=14$ for each); (i) exogenous application of JA solution, (ii) exogenous application of SA solution, (iii) exogenous application of a solution of JA + SA, and (iv) control, with exogenous application of demineralized water (see Fig. 1b). The Netherlands was hit by a drought that lasted from June to September 2018, as well as several heat waves during which temperatures of over $30 \mathrm{C}$ were recorded regularly (The Royal Netherlands Meteorological Institute (KNMI); www.knmi.nl). During this time, the plots were watered three times a week. The watering events markedly lowered the effects of drought stress in the plots, where plants were green and generally visually healthy, compared to the local vegetation, where plants were in very poor shape (scenescing or dead) well before our sampling events took place. However, the effects of extreme temperatures could not be countered and may have been a potential confounding factor in our results. 


\section{Exogenous application of plant hormones}

Jasmonic acid (( \pm$)$-1 $\alpha, 2 \beta-3-O x o-2-(c i s-2-p e n t e n y l) c y c l o-$ pentaneacetic acid) was obtained in liquid form and SA (2-Hydroxybenzoic acid) in powder form from Sigma Aldrich/Merck (Merck KGaA, Darmstadt, Germany). Both plant hormones were dissolved to $1 \mathrm{mM}$ solution in demineralized water by shaking regularly until dissolved. For each JA or SA treatment plot, a $50 \mathrm{~mL}$ tube was filled with $25 \mathrm{~mL}$ of the respective solution, mixed with $25 \mathrm{~mL}$ demineralized water, giving a solution of $0.5 \mathrm{mM}$ for each. This concentration has been used in previous studies and is known to induce defense responses in plants, but does not reach levels toxic to plants (Thaler et al. 2001; Lebeis et al. 2015). For the additive $\mathrm{JA}+\mathrm{SA}$ treatments, $25 \mathrm{~mL} 1 \mathrm{mM}$ JA solution was mixed with $25 \mathrm{~mL} 1 \mathrm{mM}$ SA solution, so that the resulting solution was $0.5 \mathrm{mM}$ for both plant hormones and the application volume was equal. The control tubes were filled with $50 \mathrm{~mL}$ demineralized water. Solutions were applied to the plots using four multi-purpose spray bottles (Gardena/ Husqvarna, Ulm, Germany), one per treatment. The sprays resulted in the vegetation being covered by a fine mist, causing dew-like droplets on the plants, and prevented dripping of the applied solutions to the soil (Thaler et al. 2001), which is important, as we were only interested in plant-mediated effects of the hormone treatments. The treatments were applied at three consecutive times on May 4, May 14 and May 29, which were dry, sunny days. The repeated application was done to mimic recurring herbivory for a prolonged period of time, as is likely to occur in nature.

\section{Phytometer plant assay and plot productivity}

In order to assess how the plant community responded to the JA and SA treatments and created soil legacies that might lead to plant-soil feedbacks, seedlings of a phytometer plant, $J$. vulgaris, were transplanted into each plot. Seeds of $J$. vulgaris that were used in this study were collected from 'De Mossel' area in the summer of 2014. Seeds were separated from their pappus, sterilized using 2.0\% hypochlorite solution and rinsed with demineralized water, in order to minimize the seed-associated microbiome. The seeds were germinated on autoclaved glass beads in a climate cabinet (light regime $16: 8 \mathrm{~h}, \mathrm{~L}: \mathrm{D}$, day temperature, $21{ }^{\circ} \mathrm{C}$, night temperature $16^{\circ} \mathrm{C}$ ). In order to maximize survival, the seedlings were transplanted in seedling trays in sterilized soil ( $\gamma$-irradiation by Synergy Health, Ede, The Netherlands), and left to grow for 3 weeks until they had 4-6 true leaves. Sterile substrate was used to prevent responses of the phytometer plants to potential pre-existing biotic soil legacies present in unsterilized substrate. Three seedlings were then transplanted in each plot, 2 weeks after the last application of plant hormones to the plots, on June 13. A plastic label was pinned next to each seedling, so that the transplanted seedlings could be relocated. The plants were carefully uprooted and harvested 5 months after planting, on November 7. Roots were washed and root and shoot biomass was dried at $70{ }^{\circ} \mathrm{C}$ for at least $72 \mathrm{~h}$, before the dry weights were measured.

After the harvest of the phytometer plants, the biomass of the vegetation of the entire plot was also clipped at soil level and dried. We refer to the total biomass of the plots in the manuscript as plot productivity, and this was used as an independent random factor in the statistical analyses as plot productivity is known to affect both plant-plant interactions (e.g., light, nutrient, space competition) and plant-insect interactions (e.g., visual cues, foraging behavior).

\section{Insect collection in experimental plots}

In order to assess how hormone application in the experimental plots affected the resident insect community in each plot, one blue sticky trap of $10 \times 10 \mathrm{~cm}$ (Koppert Biological Systems, Berkel en Rodenrijs, The Netherlands) was placed, sticky side up, in the middle of each plot for $24 \mathrm{~h}$ (see Fig. 1c). Using a stereomicroscope, the insects collected on the traps were identified to order and specified to suborder in Hemiptera. In the Hymenoptera, the distinction was made between parasitic wasps (predominantly from the superfamily Ichneumonoidea in this study) and ants (Formicidae). Insects were also categorized by their feeding guild; herbivorous insects (i.e., chewing and phloem-feeding insects), natural enemies (i.e., predators and parasitoids), and pollinators (predominantly Diptera).

\section{Predation assay using model caterpillars}

In order to assess how hormone application in the experimental plots affected the specific attraction of predators to the experimental plots, a model caterpillar predation assay was performed, modified from two recent studies (Low et al. 2014; Meyer et al. 2015). Specifically, green molding clay (JuniorKnet, Feuchtman GmbH Spielwarenfabrik, Burgbernheim, Germany) was used to create caterpillars of $6 \mathrm{~mm}$ diameter and $2 \mathrm{~cm}$ length. Caterpillars were pinned on a $2 \times 4 \mathrm{~cm}$ piece of cardboard to facilitate placement and relocation in the field (Meyer et al. 2015). Four model caterpillars were placed in each plot $(56 \times 4=224$ model caterpillars) on 18 July and left in the plots for $48 \mathrm{~h}$. After collection, each caterpillar was assessed under a stereomicroscope in order to record presence and type of bite marks on the caterpillar surface. The bite marks were classified to coarse groups (i.e., arthropod, mammal, bird, reptile; Low et al. 2014). As there were only very few ( $<5$ per group) bite marks caused by mammals, birds or reptiles, for the 
data analysis the caterpillars were scored as attacked or not attacked.

\section{Soil characteristics}

Two weeks after application of the last round of plant hormones, four soil samples were taken from each plot $(1.3 \mathrm{~cm}$ diameter, $10 \mathrm{~cm}$ depth) and homogenized for soil chemical analysis. Soil samples were air-dried at $40{ }^{\circ} \mathrm{C}$ after which the soil was sieved through a $2 \mathrm{~mm}$ sieve to remove large stones and root fragments. Three grams of the air-dried soil was transferred to a $50-\mathrm{mL}$ tube and $30 \mathrm{ml}$ of $0.01 \mathrm{M} \mathrm{CaCl}_{2}$ was added. This mixture was shaken for $2 \mathrm{~h}$ on a mechanical shaker with linear movement at $250 \mathrm{rpm}$. The samples were then centrifuged for $5 \mathrm{~m}$ at $3000 \mathrm{rpm}$ and $15 \mathrm{~mL}$ of the supernatant was filtered through a Whatman Puradisc Aqua 30 syringe filter with cellulose acetate membrane. To measure soil extractable micronutrients (Fe, K, Mg, P, S, Zn), $12.87 \mathrm{~mL}$ of the filtrate was transferred to a $15-\mathrm{mL}$ Falcon tube and $130 \mu \mathrm{L} \mathrm{HNO}_{3}$ was added. The sample was mixed using a vortex and analyzed by inductively coupled plasmaoptical emission spectrometer (ICP-OES, Thermo Scientific iCAP 6500 Duo Instrument with axial and radial view and CID detector microwave digestion system). The remaining part of the filtrate was transferred to a $15-\mathrm{mL}$ Falcon tube to measure soil $\mathrm{pH}, \mathrm{NO}_{2}+\mathrm{NO}_{3}$ and $\mathrm{NH}_{4}$. After taking a $\mathrm{pH}$ measurement (inoLab pH 7310), the soil extracts were analyzed on a QuAAtro Autoanalyzer (Seal analytical, Mequon, Wisconsin, USA).

Soil organic matter levels were determined for each plot by first drying $\sim 5 \mathrm{~g}$ (fresh weight) of field soil at $105^{\circ} \mathrm{C}$ for at least $24 \mathrm{~h}$. The dried soils were weighed and then burnt overnight at $550{ }^{\circ} \mathrm{C}$, after which they were weighed again. The organic matter was then calculated as the percentage of weight loss relative to the dry weight.

\section{Data analysis}

The effects of 'JA treatment' (yes/no) and 'SA treatment' (yes/no) on plot-level productivity were tested using a twoway ANOVA.

The effects of 'JA treatment' (yes/no) and 'SA treatment' (yes/no) on root and shoot biomass of the phytometer plant $J$. vulgaris were tested using general linear mixed models. Plot number was included as a random factor to account for multiple phytometer plants that were in the same plot. As growth of J. vulgaris is known to be influenced by competition with other plants, we also included plot productivity as an independent random factor in our statistical model.

The effects of 'JA treatment' (yes/no) and 'SA treatment' (yes/no) on arthropod numbers were analyzed using generalized linear mixed models using a Poisson distribution. As arthropod presence may vary with plot productivity, we included plot productivity as an independent random factor in our statistical model. Arthropod numbers were only analyzed for the insect orders Coleoptera, Diptera, the parasitic members of the order Hymenoptera, the Hemipteran suborders Auchenorrhyncha, Sternorrhyncha and Heteroptera, the order Thysanoptera, and the arachnid order Aranea. The number of individuals in other arthropod orders were too low for meaningful statistical analysis, but they were included in the group analyses. Arthropods were grouped by functional group (i.e., total arthropods, herbivores, "natural enemies' (predators and parasitoids) and pollinators) and the groups were analyzed using the same model.

The effects of 'JA treatment' (yes/no) and 'SA treatment' (yes/no) on the proportion of model caterpillars attacked by predators were analyzed using generalized linear mixed models using a binomial distribution. As predator presence may vary with plot productivity (and resulting openness of the canopy), we included plot productivity as an independent random factor in our statistical model.

The effects of 'JA treatment' (yes/no) and 'SA treatment' (yes/no) on soil chemistry (Fe, K, Mg, P, S, Zn, $\mathrm{NO}_{2}+\mathrm{NO}_{3}$ and $\mathrm{NH}_{4}$ ) and soil organic matter levels were tested using general linear mixed models. As soil chemistry may vary with plot productivity, we included plot productivity as an independent random factor in our statistical model.

Model assumptions were checked using QQ- and residual plots, and data were transformed to meet assumptions when necessary (and indicated as such in the respective statistical tables).

All analyses were performed in R Studio version 1.1.419 (RStudio, Inc., Boston, USA) using R version 3.3.1 (R Development Core team 2019). General linear mixed models were performed using the 'nlme' package (Pinheiro et al. 2018) and generalized linear mixed models were performed using the 'Ime4' package (Bates et al. 2015). P values from the latter were obtained using the car::Anova command from the 'car' package (Fox and Weissberg 2019).

\section{Results}

\section{Plot productivity and phytometer plant biomass}

Overall, productivity (aboveground biomass) per plot in plots treated with JA and SA did not differ significantly from controls (Table S1A). Moreover, treatment with JA and SA did not alter shoot or root biomass of phytometer plants that were transplanted in the plots after the treatments had ended (Supplementary Table S1A, Fig. 2a, b). However, there was a positive relationship between plot productivity and phytometer root biomass $\left(F_{1,54}=6.0, R^{2}=0.10, p=0.018\right.$; Fig. 2c), while phytometer shoot biomass was not related to plot productivity $\left(F_{1,54}=2.3, R^{2}=0.041, p=0.133\right.$; Fig. 2 d $)$. 

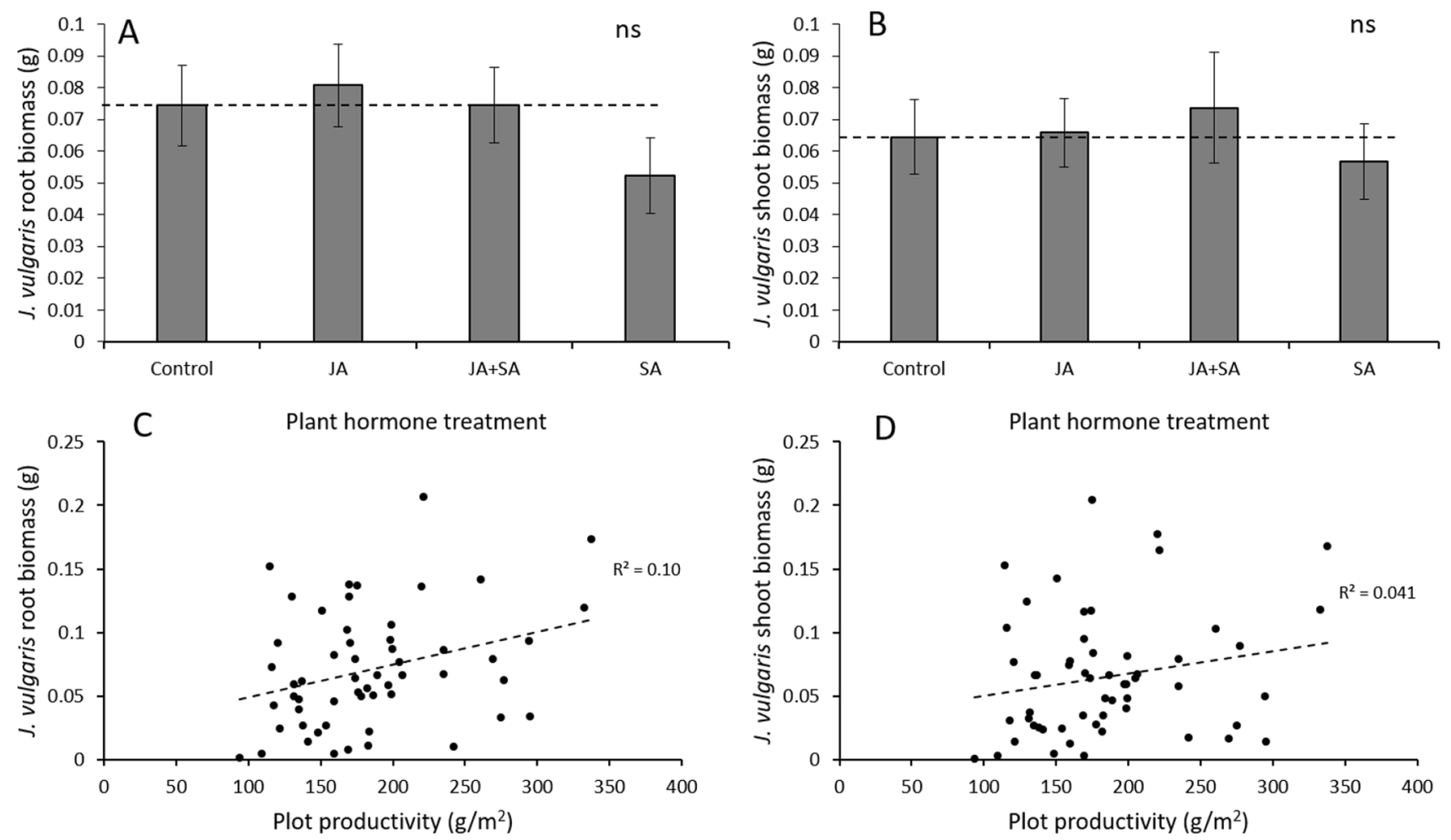

Fig. 2 Effects of simulated herbivory by exogenous phytohormone (JA and SA) application, mediated via soil, on mean $( \pm$ SE) a shoot and $\mathbf{b}$ root biomass of the focal plant, Jacobaea vulgaris per plot, and

relationships of $\mathbf{c} J$. vulgaris shoots and d roots with plot-level productivity. The dashed line represents the mean value in the control treatments

\section{Arthropod community responses}

Our arthropod collection yielded predominantly flies, grasshoppers, and ants were also collected on the sticky traps during this study (Table 1), but numbers were too aphids, planthoppers, and parasitic wasps. Various spiders,

Table 1 The effects of phytohormone treatments on average numbers per plot of insect orders and per functional group that were collected on sticky traps in the field. Presented are mean numbers, followed by their standard errors (between parentheses)

\begin{tabular}{lllll}
\hline & Control & JA & SA & JA+SA \\
\hline Collembola & $0(0.00)$ & $0.07(0.07)$ & $0(0.00)$ & $0.07(0.07)$ \\
Thysanoptera & $0.79(0.50)$ & $2.64(2.04)$ & $2.14(0.72)$ & $1.71(1.05)$ \\
Hemiptera-Heteroptera & $0.36(0.17)$ & $0.07(0.07)$ & $0.36(0.17)$ & $0.14(0.10)$ \\
Hemiptera-Auchenorrhyncha & $4.43(0.55)$ & $3.14(0.64)$ & $3.93(1.04)$ & $4.21(0.48)$ \\
Hemiptera-Sternorrhyncha & $0.14(0.10)$ & $0.21(0.15)$ & $0.29(0.13)$ & $0.64(0.20)$ \\
Orthoptera & $0.07(0.07)$ & $0.14(0.10)$ & $0.07(0.07)$ & $0.07(0.07)$ \\
Coleoptera & $0.64(0.23)$ & $0.64(0.25)$ & $0.93(0.29)$ & $0.64(0.27)$ \\
Hymenoptera-Formicidae & $0.36(0.23)$ & $0.14(0.10)$ & $0(0.00)$ & $0.14(0.10)$ \\
Hymenoptera一Parasitica & $0.71(0.19)$ & $0.79(0.19)$ & $1.36(0.31)$ & $1.57(0.42)$ \\
Diptera & $12.57(1.10)$ & $13.07(1.96)$ & $11.21(1.36)$ & $12.64(1.86)$ \\
Arachnida & $0.07(0.07)$ & $0.14(0.10)$ & $0.07(0.07)$ & $0.21(0.11)$ \\
Total arthropods & $20.14(1.31)$ & $21.14(2.66)$ & $20.43(3.06)$ & $22.14(2.51)$ \\
Total herbivores & $6.43(0.72)$ & $6.93(2.01)$ & $7.71(1.87)$ & $7.50(1.43)$ \\
Total natural enemies & $1.14(0.29)$ & $1.07(0.16)$ & $1.43(0.34)$ & $1.93(0.49)$ \\
Total pollinators & $13.29(1.16)$ & $13.93(1.93)$ & $12.64(1.48)$ & $14.29(2.06)$ \\
\hline
\end{tabular}

Output of statistical models is presented in Supplementary Table S1B 
numbers were thus only included in the analyses of total arthropod numbers.

Phytohormone treatments had little effect on numbers of most of the collected orders and most orders were low in abundance (Table 1; Supplementary Table S1B). However, JA application had a marginally significant negative effect on the number of Heteroptera collected on sticky traps, compared to plots that did not receive JA (Supplementary Table S1B). SA application had a marginally significant positive effect on the number of aphids (Hemiptera: Sternorrhyncha) collected on the sticky traps, compared to plots that did not receive SA (Fig. 3a, Supplementary Table S1B). Similarly, SA application had a positive effect on numbers of parasitic Hymenoptera collected on the sticky traps, compared to plots that did not receive SA (Fig. 3b, Supplementary Table S1B).

JA or SA application had no significant effects on arthropods when they were grouped into functional groups, although SA application had a marginally significant positive effect on numbers of natural enemies compared to plots that did not receive SA (Table 1, Supplementary Table S1).

The total number of arthropods was negatively related to plot productivity $\left(F_{1,54}=7.8, R^{2}=0.13, p=0.007\right.$; Fig. 3 c $)$,
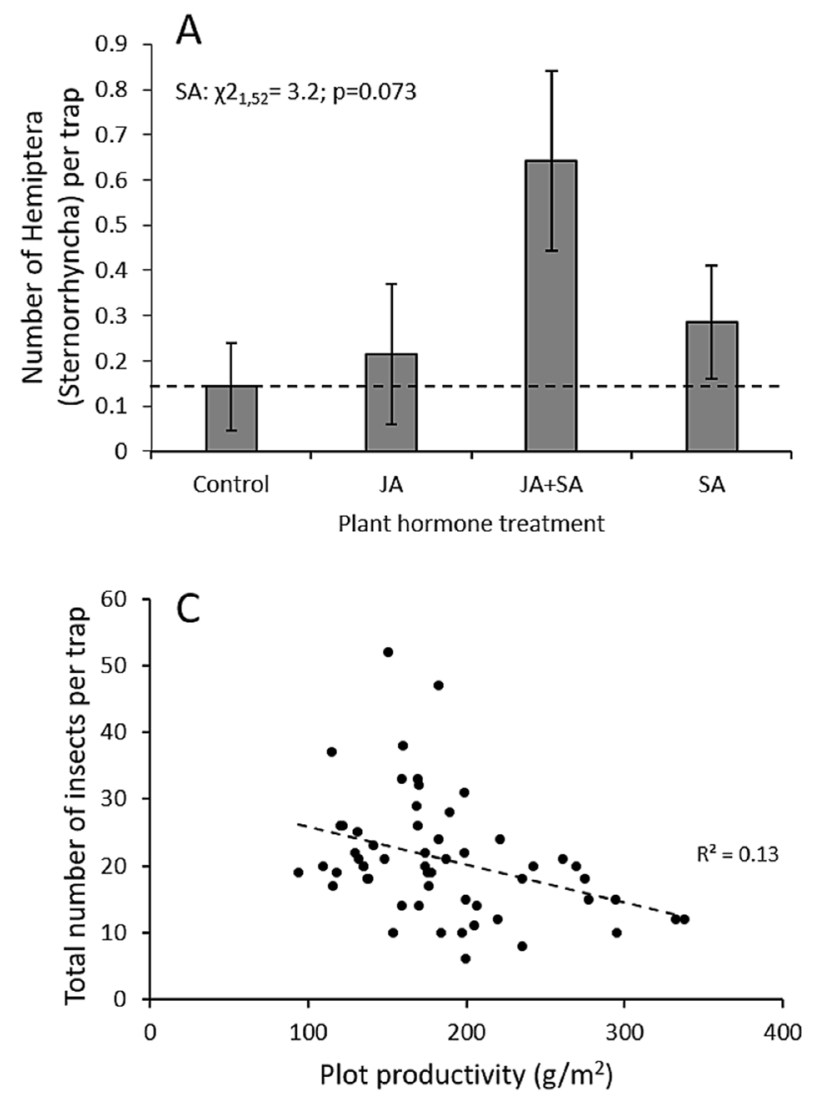

Fig. 3 Effects of simulated herbivory by exogenous phytohormone (JA and SA) application on mean ( \pm SE) number of a visiting Hemiptera, and $\mathbf{b}$ visiting parasitic Hymenoptera, and relationships between and the insect order Diptera, the most abundant order collected in the assay, followed the same pattern $\left(F_{1,54}=9.0\right.$, $R^{2}=0.14, p=0.004$; Fig. 3d).

\section{Predation of model clay caterpillars}

In total, $45 \%$ of the caterpillars that were placed in the field, were attacked by predators. Only very few bite marks were caused by birds, reptiles or mammals, but examples of bird and mammal attack marks were observed (Supplementary Fig. S1). Although attack was common, JA or SA application had no effect on the levels of predation in the field (Supplementary Table S1C) and levels of predation were also not related to plot productivity.

\section{Soil characteristics}

Phytohormone treatments had little effect on most of the measured micronutrients, or soil organic matter (Table 2, Supplementary Table S1D). However, JA application led to significantly lower levels of nitrate and nitrite in the soil, compared to plots that did not receive JA (Fig. 4a, Table 2).
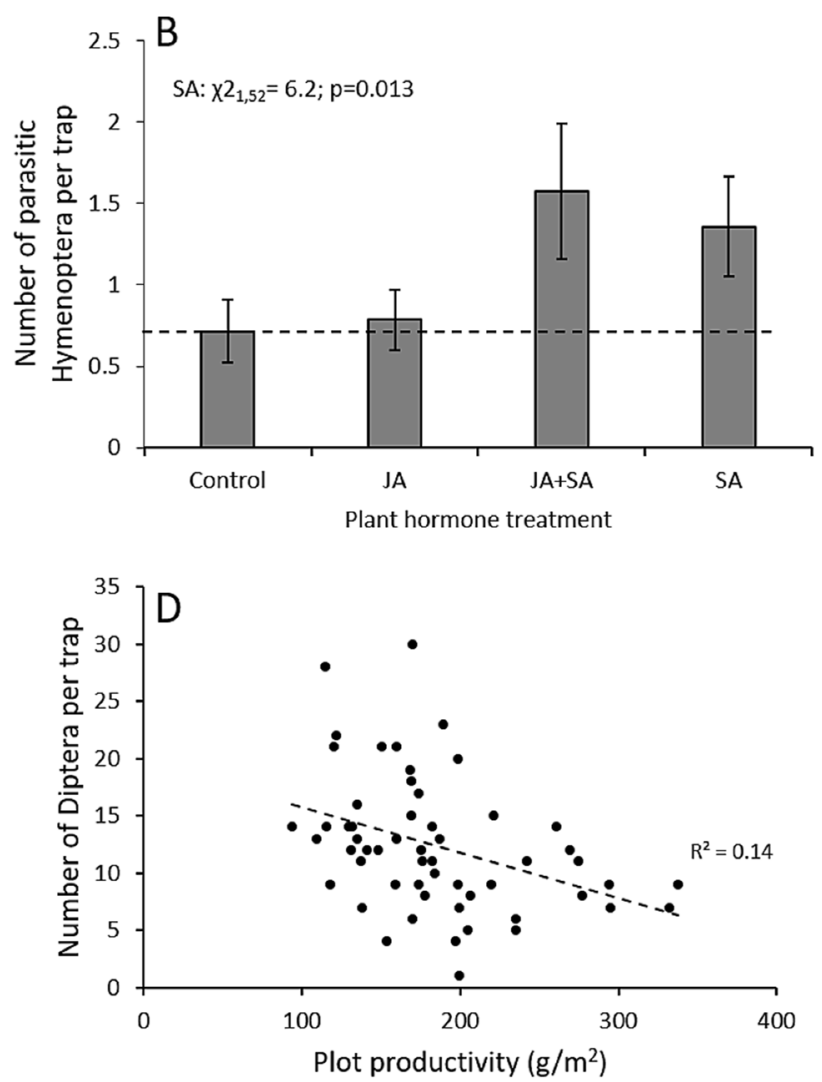

$\mathbf{c}$ total insect visitation and $\mathbf{d}$ visiting Diptera and plot-level productivity. The dashed line represents the mean value in the control treatments 
Table 2 The effects of phytohormone treatments on soil micronutrients, soil $\mathrm{pH}$ and soil organic matter. Presented are mean numbers, followed by their standard errors (between parentheses)

\begin{tabular}{lllll}
\hline & Control & JA & SA & JA + SA \\
\hline $\mathrm{NO}_{2}+\mathrm{NO}_{3}(\mathrm{mg} / \mathrm{kg})$ & $0.93(0.13)$ & $0.82(0.13)$ & $1.12(0.17)$ & $0.68(0.08)$ \\
$\mathrm{NH}_{4}(\mathrm{mg} / \mathrm{kg})$ & $2.20(0.33)$ & $2.33(0.36)$ & $1.98(0.28)$ & $1.68(0.24)$ \\
$\mathrm{Fe}(\mathrm{mg} / \mathrm{kg})$ & $0.19(0.01)$ & $0.20(0.01)$ & $0.20(0.01)$ & $0.20(0.01)$ \\
$\mathrm{K}(\mathrm{mg} / \mathrm{kg})$ & $17.16(1.48)$ & $19.51(2.57)$ & $18.90(1.50)$ & $16.66(1.70)$ \\
$\mathrm{Mg}(\mathrm{mg} / \mathrm{kg})$ & $25.97(0.84)$ & $24.33(1.13)$ & $25.35(0.83)$ & $24.76(0.99)$ \\
$\mathrm{P}(\mathrm{mg} / \mathrm{kg})$ & $4.99(0.17)$ & $4.72(0.12)$ & $4.84(0.14)$ & $4.85(0.14)$ \\
$\mathrm{S}(\mathrm{mg} / \mathrm{kg})$ & $1.58(0.10)$ & $1.57(0.06)$ & $1.56(0.08)$ & $1.56(0.08)$ \\
$\mathrm{Zn}(\mathrm{mg} / \mathrm{kg})$ & $2.15(0.07)$ & $2.01(0.08)$ & $2.08(0.10)$ & $2.04(0.07)$ \\
Soil pH & $5.12(0.01)$ & $5.14(0.02)$ & $5.13(0.02)$ & $5.12(0.03)$ \\
Soil organic matter $(\%)$ & $3.92(0.12)$ & $3.86(0.04)$ & $3.77(0.07)$ & $3.81(0.06)$ \\
\hline
\end{tabular}

Output of statistical models is presented in Supplementary Table S1D
Iron and potassium levels both showed marginally significant positive relationships with plot productivity (Fig. 4b, c).

\section{Discussion}

In this study we examined how exogenous application of the plant phytohormones JA and SA to grassland community plots, would affect plant-soil feedbacks and ecosystem characteristics under field conditions. We did not find any evidence that exogenous application of phytohormones affects plant-soil feedbacks in this study. However, we found that exogenous application of phytohormones to plant communities can affect the aboveground arthropod community that is associated with the plant community, and can also alter levels of soil nutrients.

We found that application of SA, altered the insect community associated with the plots. Application of SA led to an increased number of aphids on the sticky traps in the field plots, although this effect was only marginally significant. This is contrary to what we predicted, as SA-induced plants are expected to be better defended against inducers of the SA pathway, such as aphids. One explanation may be that SA caused aphids to leave their colonized plants in search of better host plants, as aphids have been shown to settle less quickly on SA treated plants (Cao et al. 2014). Reports of SA effects on aphid performance have previously been shown to range from no effects (Moran and Thompson 2001), to a reduction in their numbers (e.g., Schweiger et al. 2014). Other studies have observed that SA induction affected numbers of chewing herbivores, but the direction is not consistent (Bi et al. 1997; Stout et al. 1999; Felton et al. 1999). We also observed positive effects of SA application on numbers of parasitoids in the field plots. This may indicate that SA application induced plant communities to produce herbivore-induced plant volatiles; SA plays an important role in the production of herbivore-induced plant volatiles (e.g., Ozawa et al. 2000; Van Poecke and Dicke 2002) and can prime plants for the production of volatiles involved in enhanced attraction and efficacy of aphid parasitoids (Rostás and Turlings 2008; Karatolos and Hatcher 2009). We also observed a marginally significant positive effect of SA application on the total numbers of natural enemies, which was driven by the effects of SA on the presence of parasitoids. Other natural enemies, such as spiders or carabid beetles were low in abundance or absent. The latter is in line with absence of SA effects in our predation assay. Parasitoids and other natural enemies generally use volatile cues for detection of their host or prey, which cannot be mimicked by the clay caterpillars and may explain why there were no significant differences in the predation levels. Although attacks of model clay caterpillars were common, bite marks were generally caused by small arthropods, most likely by ants.

In contrast, we did not find any significant effect of JA application, on the arthropod community associated with the plots. Exogenous application of JA has been used in previous studies to mimic aboveground herbivory and is known to induce plant defense mechanisms (Thaler et al. 1996; Thaler 1999a, b; Van Dam et al. 2000; Heil et al. 2001; Stout et al. 1999; Boughton et al. 2005). Alteration of these plant hormones often yields a strong defense response that mimics a plant's natural response to herbivory (Gols et al. 1999; Bruinsma et al. 2007; Qiu et al. 2009). Jasmonic acid, when applied exogenously, activates a cascade of events inside plant tissues, that eventually leads to the production of secondary defense metabolites that may negatively affect insect performance (Thaler et al. 1996; Van Dam et al. 2000; Bruinsma et al. 2007; Qiu et al. 2009). Further, application may trigger the release of herbivore-induced volatile organic compounds, which can be used as host detection cues by natural enemies, such as predators and parasitoids (Gols et al. 1999; Kessler and Baldwin 2001). Although several studies have shown effects of JA application on the performance and abundance of insect herbivores and their natural enemies, even in the field, in this study it did not result in such effects. Our insect collection revealed that phloem 

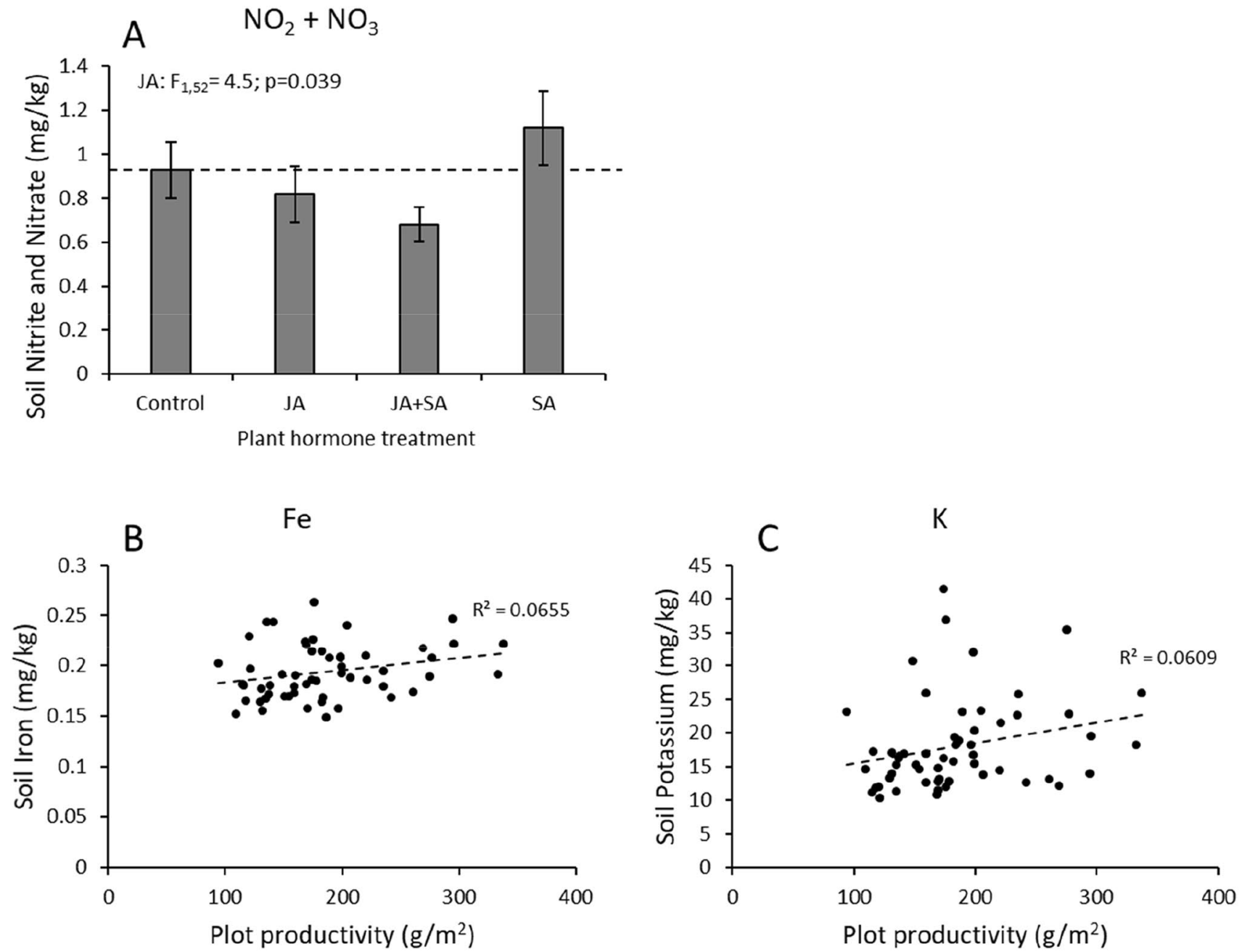

Fig. 4 a Effects of simulated herbivory by exogenous phytohormone (JA and SA) application, on mean ( \pm SE) soil levels of $\mathrm{NO}_{2}+\mathrm{NO}_{3}$, and the relationship between $\mathbf{b}$ soil Iron and $\mathbf{c}$ soil Potassium and plot productivity. The dashed line represents the mean value in the control treatments

feeders were abundant in the field site during our sampling period. However, chewers, other than a very low number of grasshoppers, were virtually absent on our collection traps. This may be one explanation of the absence of effects of JA application on insect communities. We emphasize that we must be cautious to over-generalize the results found in this study. Although our study shows some consistent patterns in changes in plot-level insect communities, we stress that (flying) insects are often good dispersers. Although we separated our field plots by a barrier of $60 \mathrm{~cm}$ of unmown vegetation, there is a risk of non-independence in insect sampling. Future studies are needed to test whether these patterns hold true over a larger spatial scale.

We also measured treatment effects on several standard soil chemical parameters, as these may also be affected by changes in phytohormonal status, as has been shown for herbivory (Bardgett and Wardle 2003). As such, shifts in soil chemical parameters may lead to contrasting plant-soil feedback responses (Van der Putten et al. 2013). We found that, generally, there was no effect of exogenous application of phytohormones on levels of the soil nutrients $\mathrm{NH}_{4}, \mathrm{Fe}$, $\mathrm{Mg}, \mathrm{P}, \mathrm{K}, \mathrm{Zn}, \mathrm{S}$ or on soil organic matter content. However, we observed a slight decrease in nitrate and nitrite levels when JA was applied to the plant communities. One explanation for this may be that plants respond to herbivory by taking up more nitrogen from the soil to compensate for tissues lost to herbivores (Holland and Detling 1990; Knops et al. 2002). Alternatively, JA-induction in plants may lead to changes in soil communities, e.g., through altered rhizodeposition, which could cause changes in soil nitrogen levels. However, we have no evidence that the JA-induced changes in soil nitrogen altered performance of either the focal plants or total plot productivity.

Contrary to expectations, phytometer plants did not respond significantly to the phytohormones that were previously applied to the surrounding plant community. This 
may indicate that JA and SA applications did not affect the composition of soil communities in this study, which is in contrast with previous studies that observe effects of manipulation of plant phytohormones in the soil microbial community (Carvalhais et al. 2013; Lebeis et al. 2015). The only measurable response we found in the plant was that $J$. vulgaris invested in root biomass in more productive plots, which is in line with the finding that $J$. vulgaris strongly responds to competition (e.g., Van de Voorde et al. 2012; Jing et al. 2015; Bezemer et al. 2018). Jacobaea vulgaris has been used as a model system to study biotic soil legacy effects that contribute to plant-soil feedbacks, and is highly responsive to soil conditioning by different plant species (Van de Voorde et al. 2012) and these responses have been ascribed to, at least in part, shifts in soil communities (Bezemer et al. 2013; Kos et al. 2015; Wang et al. 2019). This plant species, for example, responds differently to soil conditioning, depending on the presence or absence of aboveground herbivores on the plant that conditioned the soil (Kostenko et al. 2012; Bezemer et al. 2013). As such, we would expect that the test plant would have responded to potential shifts in soil microbial communities and is wellchosen to test for potential soil legacy effects.

We may speculate why we did not observe growth responses of the phytometer plants in response to exogenous JA and SA application. Soil legacy effects may be diluted in the field compared to the greenhouse because of the multitude of confounding factors that are present in the field not present in the glasshouse (Heinze et al. 2016; Heinze and Joshi 2018; Schittko et al. 2016; Heinen et al. 2018b). Insects feeding on the plant communities prior to or during the treatments may have caused levels of phytohormone induction to be leveled across plant communities. We have tried to mitigate these confounding effects by applying JA and SA relatively early in the season, when herbivory by insects is still naturally low. As a consequence, the time between the start of our treatments and transplantation of phytometer plants was roughly 6 weeks, which is relatively short in comparison with the more classical plant-soil feedback experiments, that usually condition soils for around 10 weeks. However, recent work by our group in a semi-field setup, started in the same month of the previous year, has shown that conditioning effects of plant species on the soil microbiome are detectable from as early as 1 month after transplanting into soils (Hannula et al. 2019). Finally, the effects of the drought and heatwaves may have had stronger impacts on soil biotic conditions than the phytohormonal treatments (Sheik et al. 2011; Jurburg et al. 2017). What our study shows is that testing plant-soil interactions in natural plant communities, although ecologically meaningful, is prone to high noise. Although some of this noise could be reduced in future work, for instance by planting standardized plant communities or individual plants in common garden experiments, instead of using natural vegetation, we could also conclude that other driving environmental factors may outweigh the effects of plant-soil feedbacks under natural conditions.

In conclusion, we provide evidence that JA and SA were effective in invoking specific ecosystem responses in the field that are likely mediated via the plants. Although exogenous application of phytohormones resulted in altered interactions with insects aboveground and altered levels of soil nitrogen, we could not confirm the hypothesis that exogenous application of JA and SA to plant communities in the field can affect plant-soil feedbacks in phytometer plants. We argue that future experiments testing the effects of JA and SA on plant-soil and plant-insect interactions under natural conditions should standardize experimental conditions further, to get a better understanding of the role of plant phytohormonal pathways in ecosystem characteristics in the field. At the same time, given that anthropogenic global warming is generating more extreme conditions such as heat, droughts and short-term bursts of heavy rainfall across much of the biosphere waves (Meehl and Tebaldi 2004; Christidis et al. 2015), the results of future studies need to be framed within the context of ecological consequences of humanmediated global changes.

Acknowledgements We thank Roel Wagenaar and Ciska Raaijmakers for valuable discussions on phytohormone preparation and Simon Vandenbrande for help during the initial setup of field plots. This work was funded by the Netherlands Organization for Scientific Research (NWO VICI Grant 865.14.006). This is publication number 7018 of the Netherlands Institute of Ecology (NIOO-KNAW).

Open Access This article is licensed under a Creative Commons Attribution 4.0 International License, which permits use, sharing, adaptation, distribution and reproduction in any medium or format, as long as you give appropriate credit to the original author(s) and the source, provide a link to the Creative Commons licence, and indicate if changes were made. The images or other third party material in this article are included in the article's Creative Commons licence, unless indicated otherwise in a credit line to the material. If material is not included in the article's Creative Commons licence and your intended use is not permitted by statutory regulation or exceeds the permitted use, you will need to obtain permission directly from the copyright holder. To view a copy of this licence, visit http://creativecommons.org/licenses/by/4.0/.

\section{References}

Ali JG, Agrawal AA (2012) Specialist versus generalist insect herbivores and plant defense. Trends Plant Sci 17(5):293-302

Bagchi R, Gallery RE, Gripenberg S, Gurr SJ, Narayan L, Addis CE et al (2014) Pathogens and insect herbivores drive rainforest plant diversity and composition. Nature 506(7486):85

Bardgett RD, Wardle DA (2003) Herbivore-mediated linkages between aboveground and belowground communities. Ecology 84(9):2258-2268

Bates D, Mächler M, Bolker B, Walker S (2015) Fitting linear mixedeffects models using lme4. J Stat Softw 67(1):1-48. https://doi. org/10.18637/jss.v067.i01 
Berendsen RL, Pieterse CM, Bakker PA (2012) The rhizosphere microbiome and plant health. Trends Plant Sci 17(8):478-486

Bezemer TM, Van der Putten WH, Martens H, Voorde TF, Mulder PP, Kostenko O (2013) Above-and below-ground herbivory effects on below-ground plant-fungus interactions and plant-soil feedback responses. J Ecol 101(2):325-333

Bezemer TM, Jing J, Bakx-Schotman JT, Bijleveld EJ (2018) Plant competition alters the temporal dynamics of plant-soil feedbacks. J Ecol 106(6):2287-2300

Bi JL, Murphy JB, Felton GW (1997) Does salicylic acid act as a signal in cotton for induced resistance to Helicoverpa zea? J Chem Ecol 23(7):1805-1818

Bojórquez Péreznieto H, Toresano Sánchez F, Diánez Martínez F, Palmero Llamas D, Camacho Ferre F (2013) Effect of the application of jasmonic acid and benzoic acid on grafted watermelons yield under greenhouse conditions in the southeast of Spain for mitigation of stress. J Food Agric Environ 11(1):349-352

Boughton AJ, Hoover K, Felton GW (2005) Methyl jasmonate application induces increased densities of glandular trichomes on tomato, Lycopersicon esculentum. J Chem Ecol 31(9):2211-2216

Brown VK (1984) Secondary succession: insect-plant relationships. Bioscience 34(11):710-716

Brown VK (1985) Insect herbivores and plant succession. Oikos. https ://doi.org/10.2307/3544037

Brown VK, Gange AC (1992) Secondary plant succession: how is it modified by insect herbivory. Vegetatio 101:3-13

Bruinsma M, Van Dam NM, Van Loon JJ, Dicke M (2007) Jasmonic acid-induced changes in Brassica oleracea affect oviposition preference of two specialist herbivores. J Chem Ecol 33(4):655-668

Carson WP, Root RB (2000) Herbivory and plant species coexistence: community regulation by an outbreaking phytophagous insect. Ecol Monogr 70(1):73-99

Carvalhais LC, Dennis PG, Badri DV, Tyson GW, Vivanco JM, Schenk PM (2013) Activation of the jasmonic acid plant defence pathway alters the composition of rhizosphere bacterial communities. PLoS ONE 8(2):e56457

Christidis N, Jones GS, Stott PA (2015) Dramatically increasing chance of extremely hot summers since the 2003 European heatwave. Nat Clim Change 5(1):46

Cao HH, Wang SH, Liu TX (2014) Jasmonate-and salicylate-induced defenses in wheat affect host preference and probing behavior but not performance of the grain aphid, Sitobion avenae. Insect Sci 21(1):47-55

Crawley MJ (1989) Insect herbivores and plant population dynamics. Annu Rev Entomol 34(1):531-562

Crawley MJ (1996) Plant-herbivore dynamics. Plant Ecol 401-474

De Freitas S, Thais F, Stout MJ, Sant'Ana J (2019) Effects of exogenous methyl jasmonate and salicylic acid on rice resistance to. Pest Manag Sci 75(3):744-752

De Long JR, Fry EL, Veen GF, Kardol P (2019) Why are plant-soil feedbacks so unpredictable, and what to do about it? Funct Ecol 33(1):118-128

Elkinton JS, Liebhold AM (1990) Population dynamics of gypsy moth in North America. Annu Rev Entomol 35(1):571-596

El-Wakeil NE, Volkmar C, Sallam AA (2010) Jasmonic acid induces resistance to economically important insect pests in winter wheat. Pest Manag Sci 66(5):549-554

Felton GW, Korth KL, Bi JL, Wesley SV, Huhman DV, Mathews MC et al (1999) Inverse relationship between systemic resistance of plants to microorganisms and to insect herbivory. Curr Biol 9(6):317-320

Fox J, Weisberg S (2019) An R companion to applied regression, Third edition. Sage, Thousand Oaks CA. https://socialsciences.mcmas ter.ca/jfox/Books/Companion/

Gehring C, Bennett A (2009) Mycorrhizal fungal-plant-insect interactions: the importance of a community approach. Environ Entomol 38(1):93-102
Glazebrook J (2005) Contrasting mechanisms of defense against biotrophic and necrotrophic pathogens. Ann Rev Phytopathol 43:205-227

Gols R, Posthumus MA, Dicke M (1999) Jasmonic acid induces the production of gerbera volatiles that attract the biological control agent Phytoseiulus persimilis. Entomol Exp Appl 93(1):77-86

Hairston NG, Smith FE, Slobodkin LB (1960) Community structure, population control, and competition. Am Nat 94(879):421-425

Hannula SE, Kielak AM, Steinauer K, Huberty M, Jongen R, De Long JR, Heinen R, Bezemer TM (2019) Time after time: temporal variation in the effects of grass and forb species on soil bacterial and fungal communities. mBio 10:e2635-19

Heil M, Koch T, Hilpert A, Fiala B, Boland W, Linsenmair KE (2001) Extrafloral nectar production of the ant-associated plant, Macaranga tanarius, is an induced, indirect, defensive response elicited by jasmonic acid. Proc Natl Acad Sci 98(3):1083-1088

Heinen R, van der Sluijs M, Biere A, Harvey JA, Bezemer TM (2018a) Plant community composition but not plant traits determine the outcome of soil legacy effects on plants and insects. J Ecol 106(3):1217-1229

Heinen R, Biere A, Harvey JA, Bezemer TM (2018b) Effects of soil organisms on aboveground plant-insect interactions in the field: patterns, mechanisms and the role of methodology. Front Ecol Evol 6:106

Heinze J, Joshi J (2018) Plant-soil feedback effects can be masked by aboveground herbivory under natural field conditions. Oecologia 186(1):235-246

Heinze J, Sitte M, Schindhelm A, Wright J, Joshi J (2016) Plantsoil feedbacks: a comparative study on the relative importance of soil feedbacks in the greenhouse versus the field. Oecologia 181(2):559-569

Holland EA, Detling JK (1990) Plant response to herbivory and belowground nitrogen cycling. Ecology 71(3):1040-1049

Jeffery S, Memelink I, Hodgson E, Jones S, van de Voorde TFJ, Bezemer TM et al (2017) Initial biochar effects on plant productivity derive from $\mathrm{N}$ fertilization. Plant Soil 415:435-448

Jing J, Bezemer TM, Van der Putten WH (2015) Interspecific competition of early successional plant species in ex-arable fields as influenced by plant-soil feedback. Basic Appl Ecol 16(2):112-119

Johnson SN, Rasmann S (2015) Root-feeding insects and their interactions with organisms in the rhizosphere. Annu Rev Entomol 60:517-535

Johnson SN, Clark KE, Hartley SE, Jones TH, McKenzie SW, Koricheva J (2012) Aboveground-belowground herbivore interactions: a meta-analysis. Ecology 93(10):2208-2215

Jurburg SD, Nunes I, Brejnrod A, Jacquiod S, Priemé A, Sørensen SJ et al (2017) Legacy effects on the recovery of soil bacterial communities from extreme temperature perturbation. Front Microbiol $8: 1832$

Karatolos N, Hatcher PE (2009) The effect of acetylsalicylic acid and oxalic acid on Myzus persicae and Aphidius colemani. Entomol Exp Appl 130(1):98-105

Karban R, Kuc J (1999) Induced resistance against pathogens and herbivores: an overview. Induced plant defenses against pathogens and herbivores: biochemistry, ecology, and agriculture. American Phytopathological Society Press, St. Paul, pp 1-15

Kessler A, Baldwin IT (2001) Defensive function of herbivore-induced plant volatile emissions in nature. Science 291(5511):2141-2144

Kessler A, Baldwin IT (2002) Plant responses to insect herbivory: the emerging molecular analysis. Annu Rev Plant Biol 53(1):299-328

Knops JMH, Bradley KL, Wedin DA (2002) Mechanisms of plant species impacts on ecosystem nitrogen cycling. Ecol Lett 5(3):454-466

Kos M, Tuijl MA, de Roo J, Mulder PP, Bezemer TM (2015) Speciesspecific plant-soil feedback effects on above-ground plant-insect interactions. J Ecol 103(4):904-914 
Kostenko O, van de Voorde TF, Mulder PP, van der Putten WH, Bezemer TM (2012) Legacy effects of aboveground-belowground interactions. Ecol Lett 15(8):813-821

Kulmatiski A, Beard KH, Stevens JR, Cobbold SM (2008) Plant-soil feedbacks: a meta-analytical review. Ecol Lett 11(9):980-992

Lebeis SL, Paredes SH, Lundberg DS, Breakfield N, Gehring J, McDonald $\mathrm{M}$ et al (2015) Salicylic acid modulates colonization of the root microbiome by specific bacterial taxa. Science 349(6250):860-864

Low PA, Sam K, McArthur C, Posa MRC, Hochuli DF (2014) Determining predator identity from attack marks left in model caterpillars: guidelines for best practice. Entomol Exp Appl 152(2):120-126

Ludwig D, Jones DD, Holling CS (1978) Qualitative analysis of insect outbreak systems: the spruce budworm and forest. J Anim Ecol 47:315-332

Meehl GA, Tebaldi C (2004) More intense, more frequent, and longer lasting heat waves in the 21st century. Science 305(5686):994-997

Menzel TR, Weldegergis BT, David A, Boland W, Gols R, van Loon JJ, Dicke M (2014a) Synergism in the effect of prior jasmonic acid application on herbivore-induced volatile emission by Lima bean plants: transcription of a monoterpene synthase gene and volatile emission. J Exp Bot 65(17):4821-4831

Menzel TR, Huang TY, Weldegergis BT, Gols R, van Loon JJ, Dicke M (2014b) Effect of sequential induction by Mamestra brassicae L. and Tetranychus urticae Koch on lima bean plant indirect defense. J Chem Ecol 40(9):977-985

Meyer ST, Koch C, Weisser WW (2015) Towards a standardized rapid ecosystem function assessment (REFA). Trends Ecol Evol 30(7):390-397

Moran PJ, Thompson GA (2001) Molecular responses to aphid feeding in Arabidopsis in relation to plant defense pathways. Plant Physiol 125(2):1074-1085

Ozawa R, Arimura GI, Takabayashi J, Shimoda T, Nishioka T (2000) Involvement of jasmonate-and salicylate-related signaling pathways for the production of specific herbivore-induced volatiles in plants. Plant Cell Physiol 41(4):391-398

Ozawa R, Shiojiri K, Sabelis MW, Arimura GI, Nishioka T, Takabayashi J (2004) Corn plants treated with jasmonic acid attract more specialist parasitoids, thereby increasing parasitization of the common armyworm. J Chem Ecol 30(9):1797-1808

Ozawa R, Shiojiri K, Sabelis MW, Takabayashi J (2008) Maize plants sprayed with either jasmonic acid or its precursor, methyl linolenate, attract armyworm parasitoids, but the composition of attractants differs. Entomol Exp Appl 129(2):189-199

Philippot L, Raaijmakers JM, Lemanceau P, Van Der Putten WH (2013) Going back to the roots: the microbial ecology of the rhizosphere. Nat Rev Microbiol 11(11):789

Pieterse CM, Dicke M (2007) Plant interactions with microbes and insects: from molecular mechanisms to ecology. Trends Plant Sci 12(12):564-569

Pieterse CM, Leon-Reyes A, Van der Ent S, Van Wees SC (2009) Networking by small-molecule hormones in plant immunity. Nat Chem Biol 5(5):308

Pineda A, Zheng SJ, Van Loon JJ, Pieterse CM, Dicke M (2010) Helping plants to deal with insects: the role of beneficial soil-borne microbes. Trends Plant Sci 15(9):507-514

Pineda A, Kaplan I, Bezemer TM (2017) Steering soil microbiomes to suppress aboveground insect pests. Trends Plant Sci 22(9):770-778

Pinheiro J, Bates D, DebRoy S, Sarkar D, R Core Team (2018) nlme: Linear and Nonlinear Mixed Effects Models. R package version 3.1-148. https://CRAN.R-project.org/package $=$ nlme

Price PW, Denno RF, Eubanks MD, Finke DL, Kaplan I (2011) Insect ecology: behavior, populations and communities. Cambridge University Press, Cambridge

Qiu BL, Harvey JA, Raaijmakers CE, Vet LE, Van Dam NM (2009) Nonlinear effects of plant root and shoot jasmonic acid application on the performance of Pieris brassicae and its parasitoid Cotesia glomerata. Funct Ecol 23(3):496-505
R Development Core Team (2019) R: A language and environment for statistical computing. R Foundation for Statistical Computing, Vienna, Austria. https://www.R-project.org/

Rostás M, Turlings TC (2008) Induction of systemic acquired resistance in Zea mays also enhances the plant's attractiveness to parasitoids. Biol Control 46(2):178-186

Schittko C, Runge C, Strupp M, Wolff S, Wurst S (2016) No evidence that plant-soil feedback effects of native and invasive plant species under glasshouse conditions are reflected in the field. J Ecol 104(5):1243-1249

Schweiger R, Heise AM, Persicke M, Müller C (2014) Interactions between the jasmonic and salicylic acid pathway modulate the plant metabolome and affect herbivores of different feeding types. Plant Cell Environ 37(7):1574-1585

Sheik CS, Beasley WH, Elshahed MS, Zhou X, Luo Y, Krumholz LR (2011) Effect of warming and drought on grassland microbial communities. ISME J 5(10): 1692

Steinauer K, Chatzinotas A, Eisenhauer N (2016) Root exudate cocktails: the link between plant diversity and soil microorganisms? Ecol Evol 6(20):7387-7396

Stout MJ, Fidantsef AL, Duffey SS, Bostock RM (1999) Signal interactions in pathogen and insect attack: systemic plant-mediated interactions between pathogens and herbivores of the tomato, Lycopersicon esculentum. Physiol Mol Plant Pathol 54(3-4):115-130

Thaler JS (1999a) Jasmonate-inducible plant defences cause increased parasitism of herbivores. Nature 399(6737):686

Thaler JS (1999b) Induced resistance in agricultural crops: effects of jasmonic acid on herbivory and yield in tomato plants. Environ Entomol 28(1):30-37

Thaler JS, Stout MJ, Karban R, Duffey SS (1996) Exogenous jasmonates simulate insect wounding in tomato plants (Lycopersicon esculentum) in the laboratory and field. J Chem Ecol 22(10):1767-1781

Thaler JS, Stout MJ, Karban R, Duffey SS (2001) Jasmonate-mediated induced plant resistance affects a community of herbivores. Ecol Entomol 26(3):312-324

Thaler JS, Humphrey PT, Whiteman NK (2012) Evolution of jasmonate and salicylate signal crosstalk. Trends Plant Sci 17(5):260-270

Van Dam NM, Oomen MW (2008) Root and shoot jasmonic acid applications differentially affect leaf chemistry and herbivore growth. Plant Signal Behav 3(2):91-98

Van Dam NM, Hadwich K, Baldwin IT (2000) Induced responses in Nicotiana attenuata affect behavior and growth of the specialist herbivore Manduca sexta. Oecologia 122(3):371-379

Van de Voorde TF, van der Putten WH, Bezemer TM (2012) The importance of plant-soil interactions, soil nutrients, and plant life history traits for the temporal dynamics of Jacobaea vulgaris in a chronosequence of old-fields. Oikos 121(8):1251-1262

Van der Putten WH, Bardgett RD, Bever JD, Bezemer TM, Casper BB, Fukami T et al (2013) Plant-soil feedbacks: the past, the present and future challenges. J Ecol 101(2):265-276

Van der Putten WH, Bradford MA, Pernilla Brinkman E, Voorde TF, Veen GF (2016) Where, when and how plant-soil feedback matters in a changing world. Funct Ecol 30(7):1109-1121

Van Poecke RM, Dicke M (2002) Induced parasitoid attraction by Arabidopsis thaliana: involvement of the octadecanoid and the salicylic acid pathway. J Exp Bot 53(375):1793-1799

Wang M, Ruan W, Kostenko O, Carvalho S, Hannula SE, Mulder PP et al (2019) Removal of soil biota alters soil feedback effects on plant growth and defense chemistry. New Phytol 221(3):1478-1491

Wilson EO (1987) The little things that run the world. Conserv Biol $1: 344-346$

Publisher's Note Springer Nature remains neutral with regard to jurisdictional claims in published maps and institutional affiliations. 